THE CHANGING RULES OF JUS AD BELLUM: CONFLICTS IN KOSOVO, IRAQ AND AFGHANISTAN

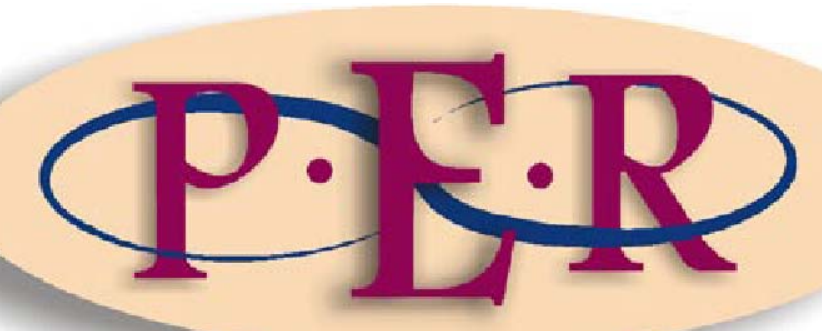

2004 VOLUME 7 No 2 


\title{
THE CHANGING RULES OF JUS AD BELLUM: CONFLICTS IN KOSOVO, IRAQ AND AFGHANISTAN
}

\author{
W Scholtz*
}

\section{$1 \quad$ Introduction}

The launching of Operation Desert Storm against Iraq in 1991 was initiated on the basis of Security Council Resolution 678 of 1990 . This action was characterized by agreement amongst various members of the United Nations (UN) and the question of the legality of this operation was not really in dispute. Subsequent armed attacks by especially the United States of America (USA) and the United Kingdom (UK) against Iraq has resulted in disagreement regarding the legality of these actions. ${ }^{1}$

Gross violations of human rights in Kosovo have lead to armed intervention in 1999, which has been coined "humanitarian intervention" by various international lawyers. This concept has also sparked a debate regarding the legality of the notion in terms of international public law. ${ }^{2}$ It is frequently asked if this concept complies with the jus ad bellum. ${ }^{3}$ The legality of the use of armed force against Afghanistan is also debatable. ${ }^{4}$ The disagreement regarding the use of force against Iraq reached an all time high when mainly the USA, UK and Australian forces attacked Iraq in 2003. These attacks resulted in international resistance.

The latter examples of the usage of armed force differ in nature. The Kosovo incident relates to the issue of humanitarian intervention, the armed attack on Afghanistan was based on a form of self-defence while Iraq was attacked on the ground of pre-emptive defence. Although these forms of the application of armed force are very different in terms of grounds of justification, they do raise difficult questions regarding the

* $\quad$ BA cum laude LLB (PU for CHE), D JUR (University of Leyden), Associate Professor at the NorthWest University (Potchefstroom Campus). I would like to thank Professor A Puttler for comments on a previous draft. All errors or omissions, however, remain my sole responsibility.

1 Gray 2002 EJIL 1-19.

2 See Gazzini 2002 EJIL 391-435.

3 It is not the intention of this article to deal with issues regarding the jus in bello.

4 See for instance editorial comments 2001 AJIL 833. 
application of the jus ad bellum and potential amendments to these rules in international public law.

It accordingly is the main purpose of this article to establish what the effects of these instances of the use of armed force are on the jus ad bellum. General rules pertaining to the use of force will be briefly sketched in the first part of this article. It is not the intent of the author to provide an extensive analysis in this regard as the application of the jus ad bellum in relation to the examples of the use of force will clarify various aspects of the general rules. The notion and legality of humanitarian intervention will subsequently receive attention in paragraph 3. The attacks on Afghanistan will briefly receive attention in paragraph 4 as to ascertain whether these attacks were legal in terms of international public law. Paragraph 5 of this article will focus on the legality of the attack on Iraq. A conclusion regarding the effects of these conflicts in relation to the jus ad bellum will be drawn from these examples.

\section{The use of force in terms of international law}

Article $2(4)^{5}$ of the Charter of the United Nations ${ }^{6}$ contains the basic prohibition on the use of force ${ }^{7}$ in international relations. ${ }^{8}$ The UN Charter requires that disputes be settled by peaceful means. ${ }^{9}$ Article $1(1)$ reads that the first purpose of the UN is to maintain international peace and security and to prevent threats of peace. The use of unilateral force will therefore contravene the principles of the Charter. Article 51 and chapter VII contains the two exceptions to the prohibition of the use of force as embodied in article 2(4). Article 51 makes provision for the right of individual or collective self-defence in the instance of an armed attack. A state may engage the right of self-defence until the

5 See for an extensive commentary on a 2(4): Randelzhofer The Charter 114-136.

6 Hereinafter the UN Charter.

7 The meaning of the term "force" in the text is ambiguous. The developing countries support a wider approach whereby all types of coercion are implied, such as physical, economical, political and psychological coercion. This interpretation of "force" is of course resisted by Western states. The prevailing view does not support the claims of the developing countries. Randelzhofer The Charter 118.

8 This provision reads that: "All Members shall refrain in their international relations from the threat or use of force against the territorial integrity or political independence of any State, or any other manner inconsistent with the purposes of the United Nations."

9 A 2(3). 
Security Council has taken action. The measures taken in terms of self-defence must be immediately reported to the Security Council. It is interesting to note that recourse to self-defence is limited due to the fact that it can only be applicable in the instance of an armed attack. Chapter VII contains the second exception to article 2(4) as it provides for the use of force to counter the threats and breaches of international peace and security as well as acts of aggression, in the form of administering economic and/or military sanctions or authorizing collective military action. Article 42 enables the Security Council to impose military sanctions in order to maintain or restore international peace.

\section{The use of armed force for humanitarian reasons}

\subsection{Introduction}

It is not the intention of this article to focus on the history of the Kosovo crisis as other authors have done this in detail. ${ }^{10}$ It would suffice to briefly focus on the developments that lead to the NATO intervention. The escalating conflict between Kosovar Albanians and ethnic Serbs resulted in the outbreak of a civil war. At the end of 1998 Serb-forces continued to build up in Kosovo and atrocities were being committed against Albanians. Two rounds of peace talks between representatives of the Federal Republic of Yugoslavia (FRY) and the Kosovar Albanians had failed and the FRY had refused to sign the American-drafted Rambouillet agreement. NATO subsequently carried out air strikes against the FRY. The Security Council did not provide authorization for the aerial campaigns of NATO in Kosovo and the actions of NATO do not constitute collective self-defence. ${ }^{11}$ The question accordingly arises whether article 2(4) makes provision for the use of force in instances other than self-defence and authorization by the Security Council. Is the use of force for humanitarian ends justified? May force therefore be used to prevent or suppress atrocities and massive violations of human rights as in the case of Kosovo? The events that took place in 1998-1999 in Kosovo have placed a great deal of

10 See Gazzini 2002 EJIL 391-435; Cohn 2002 IJSL 79-106; Sulyok 2000 Acta Juridica Hungarica 79109; Krisch 2002 EJIL 323-335; Kritisiotis 2000 ICLQ 330-359.

11 Kirgis http://www.asil.org/insights/insigh30.htm 8 Aug. See also Cassese 1999 EJIL 23. Some international lawyers are of the view that NATO is not a regional agency as provided for in ch VIII, 
focus on the concept of "humanitarian intervention" and it compelled international lawyers to revisit this notion. ${ }^{12}$ This concept has received a great deal of attention and has been the source of a lively debate in the field of international public law. ${ }^{13}$ The term "humanitarian intervention" is used where a state or several states use armed force against another state in order to enforce and protect human rights. ${ }^{14}$ The UN Charter does not explicitly deal with humanitarian intervention. The fact that the Security Council has the power to authorize coercive intervention does not mean that this authority is easily invoked. ${ }^{15}$ The Security Council has the primary responsibility for the maintenance of international peace and security. ${ }^{16}$ Article 39 of the UN Charter states that the Security Council shall determine the existence of any threat to the peace, breach of peace, or act of aggression and it can take measures involving the use of force in response. The effect of article 27(3) of the UN Charter is that a Security Council Resolution to authorize intervention is subject to the consent of any of the five permanent members. A single permanent member can therefore prevent the authorization of humanitarian intervention. ${ }^{17}$ The authority also requires an affirmative vote by nine members of the fifteen Council members. This procedure has proved not to be efficacious. ${ }^{18}$ An example of this is the instance where China vetoed a draft resolution that was aimed at the extension of the presence of peacekeeping forces in Macedonia for another six months. Canada, France, Germany, Italy, the Netherlands, Slovenia, the UK and the USA sponsored the draft resolution. ${ }^{19}$ Thirteen states voted in favour of this resolution while Russia abstained from voting. The requirements in article 27(3) may lead to a situation where a state or group of states uses force to secure human rights in other states in the absence of the authorization of the Security Council.

It is accordingly important to dissect the various possible justifications that may exist for the usage of force on the basis of humanitarian intervention.

but a military alliance. It is not the intention of this article to scrutinize these arguments. See Falk http://www.asil.org/ajil/kosovo.htm 7 Jun; Gazzini 2002 EJIL 430ff.

12 Henkin http://www.asil.org/ajil/kosovo.htm 1 Jun.

13 Eg Cohn 2002 IJSL 79-106; Krisch 2002 EJIL 323-335; Kritisiotis 2000 ICLQ 330-359.

14 Doehring Völkerrecht 431.

15 The power to authorize an intervention can originate from a 42 of the UN Charter.

16 A 12 and 24 of the UN Charter.

17 Henkin http://www.asil.org/ajil/kosovo.htm 2.

18 Charney http://www.asil.org/ajil/kosovo.htm 1 Aug. Unanimity has rarely been reached or where it was reached, it was not enforced. Randelzhofer The Charter 126.

19 See Press Release http://www.maknews.com/html/articles/un_res_1371.htm 3 Jul. 


\subsection{Textual interpretation of article 2(4) of the UN Charter}

Certain scholars argue that article 2(4) does not prohibit unilateral force in general, but force against the political independence and territorial integrity of a state or recourse to force inconsistent with the principles of the $U N$ Charter. ${ }^{20}$ In terms of this argument the use of force to protect human rights is not directed against the political independence and territorial integrity of a state and it is not inconsistent with the purposes of the Charter as respect for human rights is one of the aims thereof. ${ }^{21}$ The use of force is accordingly justified to end atrocities and large-scale deprivation of life and humanitarian intervention does not violate article 2(4). This argument is, however, flawed and cannot be accepted. ${ }^{22}$ The terms "territorial integrity" and "political independence" do not restrict the scope of the prohibition of the use of force and cover any kind of transboundary use of armed force. ${ }^{23}$ Most forms of the implementation of armed force therefore falls under the first two prohibitions and any other forms are covered by the catch-all phrase which outlaws the threat or the use of force "in any matter inconsistent with the Purposes of the United Nations". It is after all the main purpose of the UN Charter to ensure the maintenance of peace. $^{24}$

\subsection{The role of the sovereignty of states}

The international legal system has undergone changes since the founding of the UN. State sovereignty was to a great extent the center of attention when the Charter came into force. ${ }^{25}$ Article 2(7) contains a reference to the state sovereignty of members of the $\mathrm{UN} .{ }^{26}$ Reisman ${ }^{27}$ is of the opinion that:

None of us who are compelled to ask hard questions about the lawfulness of the Kosovo action is a consistent strict constructionist of the Charter. After all, who

20 See Byers 2002 EJIL 26.

21 Doehring Völkerrecht 433.

22 See also Schachter International Law 118.

23 Randelzhofer The Charter 123.

24 A 1(1) of the UN Charter.

25 Charney http://www.asil.org/ajil/kosovo.htm 1 Aug: NATO's Campaign.

26 A 2(7) states that: "Nothing contained in the present Charter shall authorize the United Nations to intervene in matters which are essentially within the domestic jurisdiction of any state or shall require the Members to submit such matters to settlement under the present Charter; but this principle shall not prejudice the application of enforcement measures under Chapter VII."

27 Reisman http://www.asil.org/ajil/kosovo.htm 9 Jun. 
amongst us insists on a textual interpretation of article 2(7)? But we are all stricter when it comes to reading article 2(4).

It is accordingly reasoned that the flexible interpretation of article 2(7) has an effect on article 2(4). The basis for this argument is that the defense of domestic jurisdiction in terms of sovereignty cannot be used as an excuse for human rights violations. ${ }^{28}$ The right to violate human rights in a gross fashion is therefore removed from the sphere of political independence. It is argued that the UN Charter cannot be changed without resulting in adjustments in other parts of the Charter. The argument furthermore entails that the inefficiency of the procedures of the Security Council results in a lack of action where humanitarian intervention is needed and it is not practical that the council has the exclusive power to decide in these circumstances which course of action must be undertaken. The question accordingly arises whether this argument can find support?

State sovereignty does not entail that a state as a member of the international community is free from certain responsibilities to its own citizens and to other members of the international community. ${ }^{29}$ The international dimension to various activities, such as transboundary pollution, has lead to the development of international regulations to ensure the effective management of such issues. ${ }^{30}$ This leads to a situation where the notion of sovereignty is changing in those areas, which were considered to be within the exclusive jurisdiction of States. This indeed allows for a more flexible approach regarding the interpretation of article 2(7). The notion of state sovereignty must be viewed in the context of the three sets of values that form the basis for inter-state relations: peace, ${ }^{31}$ human rights ${ }^{32}$ and self-determination. ${ }^{33}$ They constitute a hierarchy of values in the sense that peace must always be the ultimate purpose where a conflict arises between the values. These values can be interdependent in various instances. The

28 See also Falk http://www.asil.org/ajil/kosovo.htm 7 Jun. It must be kept in mind that in the instance of Kosovo, it was not the UN that intervened in the domestic jurisdiction of another state. The argument is, however, relevant to the question whether a 2(4) has been changed through developments in the interpretation of a 2(7).

29 Sovereignty entails that a distinction is made between two elements: the state vested with rights and obligations on the one hand and the state, which is a sovereign creator of law in the international public law arena. Strydom 1989 JJS 36.

30 Two factors are seen to be most important regarding the eroding of state sovereignty: global economic integration and the detrimental human impact on the environment. Lee http://www.bu.edu/wcp/Papers/Poli/PoliLee.htm 14 Jun.

31 A 1(1) of the Charter.

32 See a 1(3) of the Charter.

33 See a 1(2) of the Charter. 
existence of peace may be dependent on the adherence to the protection of international human rights. The fact that peace is the highest value does not mitigate the importance of the other values as well as the role of these values in the promotion of peace. ${ }^{34}$ Articles 55 and 56 of the UN Charter implore all members to take action to promote respect for and observance of human rights and fundamental freedoms for all. The broad acceptance of human rights also has an influence on the concept of state sovereignty. ${ }^{35}$ Reliance on state sovereignty in terms of article 2(7) can no longer serve as a reason for nonintervention where gross violations of human rights are committed. Sovereignty therefore entails, in the field of human rights, that the power of the state must be restricted and that the state has an obligation in this regard to protect the human rights of its citizens. ${ }^{36}$ The state must furthermore also serve as an agent to protect its citizens from harm from other parties, such as third states. The responsible exercise of sovereignty can promote human rights just as the irresponsible exercise thereof can be to the disadvantage of human rights.

It is very important to realize that the acceptance of the flexible approach to sovereignty, does not imply that article 2(4) can be interpreted in a way that permits the use of unilateral armed force for humanitarian reasons. This will render the content of article 2(4) meaningless. Articles 2(7) and 2(4) furthermore differ as article 2(4) is a jus cogens norm whereas article 2(7) does not have the same status. ${ }^{37}$ The fact that article 2(7) has been given content regarding the implication of sovereignty in relation to the other values in the Charter, does not imply that humanitarian intervention in the absence of authorization of the Security Council can be accepted. ${ }^{38}$ The fact that a state exercises its sovereignty in a way that does not pay heed to human rights does not warrant illegal unauthorized intervention and a violation of article 2(4).

34 Mertus is of the opinion that to emphasize security without having regard for human rights implies that the promotion of peaceful and just societies is sacrificed. Mertus http://www.asil.org/insights/insigh31.htm 7 Jun.

35 A great deal of agreements pertaining to human rights are in force, such as the Convention on the Prevention and Punishment of the Crime of Genocide 1948; International Covenant on Civil and Political Rights 1966; International Covenant on Economic, Social and Cultural Rights 1966; Declaration on the Elimination of Discrimination against Women 1979; Convention against Torture and Other Cruel, Inhuman or Degrading Treatment or Punishment 1984: and the Convention on the Rights of the Child 1989.

36 Bennoune 2002 EJIL 243-262.

37 This will be discussed in par 3.4ff.

38 See for an opposing view: Thürer 2000 Archiv des Völkerrechts 6. 


\subsection{Humanitarian intervention as an emerging norm of customary law}

It has been argued that the use of armed force in Kosovo established the emergence of a new customary rule in favour of humanitarian intervention. ${ }^{39}$ The obligation of states to respect human rights is an obligation erga omnes and this implies that any state or a collective group of states has the right to take steps, excluding the unilateral use of force, to attain such a respect. ${ }^{40}$ In terms of this argument the resort to unilateral armed force for reasons of humanitarian intervention may gradually become justified under strict conditions. If a humanitarian intervention rule evolves in the world community, it would constitute an exception to the rule of collective enforcement based on the authorization of the Security Council. This would then serve as an exception similar to the exception in article $51 .{ }^{41}$ In order to establish whether a rule can be recognized as customary international law, the requirements of opinio juris and usus would need to be met. ${ }^{42}$ In this instance these requirements will not be easily met. The G77 group issued an unequivocal statement that unilateral humanitarian intervention is illegal according to international law. ${ }^{43}$ It would be hard to meet the requirement of usus due to the fact that unilateral humanitarian intervention is the exception rather than the rule. ${ }^{44}$ In this regard some international scholars argue that only physical acts can be seen as State practice and therefore any State, which wants to oppose or support the formation of new customary law must act in a decisive manner. ${ }^{45}$ According to this viewpoint mere statements or

39 Byers 2002 EJIL 27.

40 Strydom 1988/1989 SAYIL 52ff. The ICJ characterized obligations erga omnes as commitments towards the international community as a whole. Par 33 and 34; Barcelona Traction, Light and Power Company, Ltd Second Phase, ICJ Reports 1970. Examples of obligations erga omnes may be found in general international law as well as treaty law. See also par 40 of the separate opinion of Kooijmans $\mathrm{j}$ in Legal Consequences of the Construction of a Wall in the Occupied Palestinian Territory (Advisory Opinion) ICJ Reports 2004.

41 The exceptions would have some commonalities: they would be justified by special circumstances, must constitute an extrema ratio, must be strictly limited for the purpose of stopping the atrocities, must be proportionate and must yield to collective enforcement under UN authority as soon as possible.

42 See Dugard International Law 24.

43 Par 54; Declaration of G77 http://www.nam.gov.za/documentation/southdecl.htm 9 Jun. The 133 States that issued the declaration consists of Asian States, African States, Latin American States and Arab States.

44 The ICJ in the Nicaragua case stated that: "while the United States might form its own appraisal of the situation as to respect for human rights in Nicaragua, the use of force could not be the appropriate method to monitor or ensure such respect" at par 268; Case Concerning Military and Paramilitary Activities in and Against Nicaragua (Nicaragua $v$ United States of America)(Merits Judgement) ICJ Reports 1986. Hereinafter referred to as the Nicaragua case.

45 Byers 2002 EJIL 30. See for an extensive discussion pertaining to developments in this field: Roberts 2001 AJIL 757-791. 
claims would not suffice. This viewpoint tends to give more influence to the powerful States in the formation of customary law. Literature in the United States suggests that more powerful States matter more regarding the formation of customary law. ${ }^{46}$ This notion violates the principle of sovereign equality.

It must furthermore be kept in mind that article 2(4) is a jus cogens norm. ${ }^{47}$ This concept was codified in the Vienna Convention. ${ }^{48}$ Article 53 states that a treaty shall be void if it conflicts with a peremptory norm of general international law as a norm accepted and recognized by the international community of states as a whole as a norm from which no derogation is permitted and which can be modified only by a subsequent norm of general international law having the same character. ${ }^{49}$ The violation of jus cogens norms is a violation against the international community as a whole and the use of force against one state implies the use of force against all states. It is therefore important to establish if the restrictions of the use of force have been changed by other norms of jus cogens.

A jus cogens norm has the highest hierarchical position among the other norms and principles of international law. Jus cogens norms are peremptory and non-derogable. ${ }^{50}$ In order to achieve recognition as jus cogens, a norm must be accepted and recognized as a peremptory norm by the international community of states as a whole as indicated in article 53 of the Vienna Convention. ${ }^{51}$ In the light of the importance of the norms in question, such an acceptance and recognition would not be lightly presumed. The fact that article 53 refers to the acceptance and recognition by the international community as a whole is a strict requirement for the creation of a jus cogens norm.

In terms of the wording of article 53 a jus cogens norm can be amended by a norm of the same nature. Article 64 of the same Convention also makes provision for the emergence of a new peremptory norm of general international law. The modification of a jus cogens

46 Byers 2002 EJIL 31.

47 Charney http://www.asil.org/ajil/kosovo.htm 9. See Strydom 1988/1989 SAYIL 44. Originally the notion of jus cogens applied only to treaty relationships. Subsequent developments have indicated the desire of the international community to apply this notion in a much broader context. Danilenko LawMaking 213.

48 Vienna Convention on the Law of Treaties 1969, hereinafter referred to as the Vienna Convention.

49 It is very controversial whether the concept of jus cogens is applicable outside the domain of treaty law. See De Wet Powers of the UN 187. The Charter is also a treaty.

50 See the discussion in Danilenko Law-Making $219 \mathrm{ff}$.

51 Danilenko Law-Making 235. 
norm can only be done via a peremptory law-changing process that does not deviate from the original law-making process whereby the original norm was established. ${ }^{52}$ Any modification could therefore only occur if it is sanctioned by a new norm, which is accepted and recognized as provided for in article 53 of the Vienna Convention. The customary process can therefore not be a suitable mechanism to amend jus cogens norms in a treaty due to the fact that acts constituting new practice aimed at modification of such a jus cogens rule would be invalid $a b$ initio. The consent of other states not to adhere to the existing norm of jus cogens does not change the situation. The modification of an existing jus cogens norm in a treaty must take place via a general multilateral treaty that embodies a peremptory norm that is in line with article 53. It must furthermore be taken into account that it is doubtful that a customary norm in favour of humanitarian intervention has emerged. The jus cogens restrictions relating to the recourse to armed force were and are not changed by the actions in Kosovo. ${ }^{53}$

\subsection{Other justifications for humanitarian intervention}

The concept of humanitarian intervention cannot be supported by the existence of a rule of customary international law in this regard. The question may therefore be asked whether the concept of humanitarian intervention can be justified on other grounds. It would be worthwhile to briefly focus on arguments of various scholars in this regard. Schachter is of the opinion that it is undesirable to allow a rule of humanitarian intervention and that it would be better to acquiesce in a violation that is considered necessary and desirable. ${ }^{54}$ Henkin also follows the same line of reasoning and is of the opinion that the lesson of Kosovo is that states will first act and then challenge the Security Council to terminate the action. ${ }^{55}$ A permanent member of the council could by means of a veto ensure that such a resolution is not adopted. The Security Council will therefore acquiesce in the decision to intervene. Henkin finds support for his statement in the adoption of Resolution $1244 .{ }^{56}$ This Resolution seems to ignore the events that took place prior to its existence. This Resolution does not condemn the use of force against the FRY and indeed does not even make mention of it. It is, however, questionable whether

52 Danilenko Law-Making 250.

53 Concurring, Franck http://www.asil.org/ajil/kosovo.htm 12 Jun.

54 Schachter International Law 126.

55 Henkin http:// www.asil.org/ajil/kosovo.htm 1 Jun.

56 Security Council Resolution 1244 of 1999. 
this resolution serves as evidence for the acquiescence of the intervention. It is through this resolution that the Security Council took control of the situation in Kosovo and addressed urgent matters in terms of a pragmatic approach. This "supposed realist" approach of Henkin and Schachter undermines the existence of international public law regarding recourse to armed conflict. ${ }^{57}$ The fact that ex post facto acceptance of the intervention takes place does not change the fact that recourse to armed conflict might have been illegal. This pragmatic acceptance of illegality opens up a wide gap for abuse. The "supposed realist" approach constitutes an acceptance of the contravention of international law "where it is necessary and desirable". States may accordingly choose to breach international law in these circumstances. It is clear that danger also exists where the contravention of law on the basis of unclear criteria is accepted.

Doehring has defended the notion of humanitarian intervention with an analogous application of article 51 of the Charter. ${ }^{58}$ In terms of this concept gross violations of human rights give rise to a breach of obligations erga omnes. The argument is that article 51 finds analogous application and can be used as a justification ground for intervention due to the fact that these violations are mostly accompanied by an element of force. Doehring further argues that oppressed people have legal subjectivity and that gross violations of human rights give rise to a right to self-defence analogous to the right contained in article 51. Other States, as carriers of legal subjectivity, can therefore provide "emergency help" (Nothilfe) to oppressed individuals. The arguments of Doehring are based on moral considerations, which are not supported by international law. This is also clear from the statement of Doehring that it would be absurd to accept that the Charter prohibits humanitarian intervention where this could save lives. ${ }^{59}$ The analogous application of article 51 cannot be supported, because article 51 should be

57 Moore identifies two wrong schools of thought on the subject of jus ad bellum. The "supposed realist" school is the group that is of the opinion that international rules are not really enforced and therefore not important. They tend to ignore the importance of international public law and the prohibition against aggression. The "minimalists" do not focus on the illegality of an attack, but rather curtail the right of self-defence through a variety of implausible interpretations of the UN Charter. This group also ignores the importance of the role of law in deterring aggression. Moore http://www.fedsoc.org/Publication/Transcripts/useofforce.htm 10 Jun.

58 Doehring Völkerrecht 432.

59 Doehring Völkerrecht 436. 
interpreted restrictively. ${ }^{60}$ The prevailing opinion furthermore rules out the use of force as a permissible countermeasure in the case of the violation of obligations erga omnes. ${ }^{61}$

Various authors have tried to draw up conditions under which humanitarian intervention can be permissible. ${ }^{62}$ These criteria cannot, however, transform an illegal intervention into a lawful one. Criteria for humanitarian intervention may be useful in the instance where the Charter is amended to provide for this concept under strict conditions. Established criteria can then serve as conditions, which must be complied with in order to constitute humanitarian intervention. It is in this context of interest to focus on the deliberations of the Axworthy Commission. This international commission is concerned with the question whether and when it is permissible to implement humanitarian intervention. ${ }^{63}$ The Axworthy Commission has drafted principles and grounds for humanitarian intervention, which must ensure that states do not use the concept of humanitarian intervention for their own selfish interests. In terms of the principles of the Commission, humanitarian intervention may only take place when a high loss of human life has already occurred or is feared or where an ethnical cleansing has started or is feared. It is furthermore stated that members should pursue authorization through the Security Council. The Commission proposes that the five permanent members of the Security Council must agree that they will refrain from making use of their veto right to impair the approval of a resolution aimed at humanitarian intervention, which is supported by the majority of the members. Members must refrain from using their veto right where the national interests of members are not affected. In the instances where the Security Council refuses a motion for humanitarian intervention this proposal may be taken to the General Assembly or measures may be taken in terms of chapter 8 of the Charter, provided that subsequent authorization will be sought. This principle opens up the possibility for regional organizations to first act in contravention with article 2(4) and then to seek retroactive justification for their actions. This is clearly not an optimal approach and may lead to abuse. Another problem with these grounds and principles for humanitarian intervention is that it may be possible for a powerful state to indicate that the requirements for the justification of humanitarian intervention are met and such a

60 Randelzhofer The Charter 677.

61 Hilpold 2001 EJIL 453.

62 See for instance: Cassese 1999 EJIL 27; Thürer 2000 Archiv des Völkerrechts 7. 
state may then pursue its own self-interest. It is also doubtful whether powerful states will adhere to the proposed grounds and principles in the instance where they pursue selfinterest. The requirements of a high loss of life and ethnical cleansing can also be subjective in nature and states may manipulate this to suit their own needs. Although critique may be voiced against the proposals of the Commission, the results of the deliberations of this commission may prove to be useful in the event where the Charter can be amended to introduce the concept of humanitarian intervention.

The armed intervention in Kosovo is illegal due to the fact that it is in contravention of article 2(4) of the UN Charter. The acceptance of the emergence of a customary rule of humanitarian intervention is not supported by evidence. Various concerns furthermore exist in this regard. The fear exists that the use of force is once more becoming an accepted means of conducting international affairs whereby the interests of a small group of powerful states are promoted. ${ }^{64}$ This development takes place in line with the development of a concept of "limited sovereignty" in favour of the more powerful states. ${ }^{65}$ The arguments contesting the concept of humanitarian intervention highlight the dangers that may accompany the introduction of the concept of armed intervention without the permission of the Security Council. It is most probable that major powers will abuse the notion of humanitarian intervention and apply the will of a collective entity, under the supervision of a single superpower, which may be detrimental to the individuals in a particular state. It is not without good reason that the restrictions to the recourse of armed force are jus cogens. Caution should be applied to ensure that armed force is not a resort for a few major powers that decide unilaterally when and where to use it. A few state actors should not acquire the privilege to regulate the international plane and to rewrite international law as they please. The need to intervene in situations where atrocities against humanity are committed has lead to the development of arguments that intend to justify the use of unilateral armed force for humanitarian purposes. It is clear that most of these arguments are superficial and does not satisfy questions regarding the legality of humanitarian intervention. These arguments merely reflect a notion of reality that international public law does not provide for unilateral

63 Williams 2002 Vereinte Nationen Zeitschrift für die VN 10ff. It is not the intention of this article to explore the proposals of this Commission in great detail.

64 Köchler http://www.i-p-o.org/koechler-intervention.pdf 20 Jun.

65 Ibid. 
humanitarian intervention. It is not useful to construct arguments that are not in line with the principles of international public law in order to justify the actions of major powers. The morality of these arguments is used as an excuse for the procedural shortcomings of the intervention in Kosovo. Morality is also a driving force behind the acceptance of the intervention in Kosovo.

The status quo regarding humanitarian intervention provides the legal scholar with a moral dilemma due to the fact that it supposes that gross violations of human rights may occur without any intervention where the Security Council has not provided authorization due to the differences amongst members. Certain powers may have recourse to armed force without permission of the Security Council where atrocities take place. The moral inclination to take action must, however, be distinguished from the legal questions regarding humanitarian intervention. The restrictions pertaining to armed force are necessary to ensure that the major powers do not rewrite international law based on a concept of the use of force based on the excuse of humanitarian intervention. This will result in anarchy in the field of international law.

\section{$4 \quad$ Military actions in Afghanistan}

\subsection{Introduction}

On September 11, 2001, the USA was the victim of attacks carried out by Al Qaeda members who crashed two commercial airplanes into the World Trade Center towers, one into the Pentagon and another into a field into Shanksville, Pennsylvania. ${ }^{66}$ On October 7 , 2001, President Bush invoked the United States' inherent right to self-defence and ordered U.S. armed forces to initiate action against members of Al Qaeda and the Taliban regime in Afghanistan. The North Atlantic Council of NATO decided that the attack against the USA was an action covered by article 5 of the Washington Treaty, whereby an armed attack against one or more of the Allies in Europe or North America "shall be considered an attack against them all". The use of force in this regard was essentially

66 See for an extensive description of the facts: Murphy 2002 AJIL 237ff. 
based on article 51 of the Charter. ${ }^{67}$ The Security Council has not adopted a resolution under chapter VII of the Charter to authorize the use of force. ${ }^{68}$ The use of armed force in this instance is furthermore clearly not a case of humanitarian intervention. ${ }^{69}$ The actions against Afghanistan have accordingly resulted in a debate regarding the legality of these actions. ${ }^{70}$ Various authors have engaged in this debate and it would not be meaningful to duplicate these contributions. ${ }^{71}$ It would suffice for the purpose of this article to briefly reflect on the effect of these actions in Afghanistan in relation to the jus ad bellum.

\subsection{Justifications for the attacks against Afghanistan}

The reliance on article 51 of the Charter for the justification of the attacks against Afghanistan implies that the attacks against the USA must have been "armed attacks" as provided for in the provision of article 51. The historical context of article 51 of the Charter suggests that armed attacks only relate to attacks between states. ${ }^{72} \mathrm{~A}$ theological reading of article 51, however, supports an interpretation that focuses on the impact of the attack rather than the origin of the attack. ${ }^{73}$ The gravity of the attacks on the USA may therefore constitute an "armed attack" if a theological approach of article 51 is followed. A second prerequisite is the fact that self-defence in terms of article 51 must be directed against the state, which was responsible for the armed attack if the territorial sovereignty of that state is infringed. Originally self-defence was only justified where it was directed against states and not other entities. ${ }^{74}$ In the instance of the Afghanistan conflict, $\mathrm{Al}$ Qaeda was responsible for the attacks against the USA. The actions of the Al Qaeda were attributed to the Taliban regime and the state of Afghanistan. ${ }^{75}$ The reason for the attack

67 Stahn 2002 ZaoRV 211.

68 See Security Council Resolutions 1368 and 1373 of 2001. Resolution 1368 reaffirms the inherent right of individual and collective self-defence in accordance with the Charter, while Resolution 1373 obliges all member states to deny financing, support and safe haven to terrorists. These resolutions did not authorize self-defence in terms of ch VII of the Charter.

69 Ibid.

70 See for instance editorial comments 2001 AJIL 833.

71 See for instance: Franck 200195 AJIL 839. See also the contributions of various authors at: http://www.ejil.org/forum_WTC/ and http://www.asil.org/terrorind.htm 2 Aug.

72 This is supported by a 1 of the Definition of Aggression GA Resolution 3314. The ICJ largely equated the definition of aggression with the concept of an "armed attack" at Nicaragua case par 195.

73 See Mégret http://www.ejil.org/forum_WTC/ 3 Aug. Stahn 2002 ZaoRV 213. See also par 35 of the separate opinion of Kooijmans $\mathrm{j}$ in Legal Consequences of the Construction of a Wall in the Occupied Palestinian Territory (Advisory Opinion) ICJ Reports 2004.

74 Mégret http://www.ejil.org/forum_WTC/ 19.

75 Murphy AJIL 245 and 246. 
of the state of Afghanistan was the fact that Afghanistan supposedly allowed Al Qaeda to undertake terrorist attacks against the USA and did not take action to put an end to the actions of this entity. This issue raises the question whether the mere harbouring of terrorists is sufficient to hold a state accountable for an armed attack. It must be noted in this regard that states may incur legal responsibility for tolerating terrorism from its territory. ${ }^{76}$ Even if it can be argued that Afghanistan failed to comply with its obligations in terms of international law, this still does not warrant self-defence in terms of article 51. State responsibility for harbouring terrorists must be distinguished from state responsibility for an armed attack on another state by the same terrorists. The question accordingly arises whether Afghanistan can be held responsible for the armed attacks of Al Qaeda against the USA. The International Court of Justice adopted the so-called "effective control" test, in terms of which a state can be liable for the acts of those over whom it has effective control. ${ }^{77}$ The court held that a high degree of control over a military group was necessary and that the control be exercised with respect to the specific relevant operation. The mere assistance in the form of the provision of weapons or logistical support would not constitute an armed attack. The tolerance of the presence of terrorists on a state's territory is an insufficient reason in terms of present international law to impute to the host an armed attack of the terrorists. ${ }^{78}$ The "effective control" test is

76 See for instance the Declaration on Principles of International Law GA Resolution 2625 (XXV), 24 October 1975. This declaration inter alia states that: "Every State has a duty to refrain from organizing, instigating, assisting, or participating in ... terrorist acts in another State or acquiescing in organized activities within its territory directed towards the commission of such acts."

77 Par 105, 119 and 230; Nicaragua case.

78 Mégret http://www.ejil.org/forum_WTC/ 23. See for an opposing view Stahn 2002 ZaoRV 221. Stahn is of the view that the "overall control" test as adopted by the Appeals Chamber of the ICTY in the Tadic case may be fulfilled in the Afghanistan case. In terms of this test, control required by international law may be deemed to exist when a State or a Party to the conflict has a role in organizing, coordinating or planning the military actions of the group, in addition to financing, training and equipping or providing operational support to that group. Par 137; ICTY, Appeals Chamber, Prosecutor v. Tadic ILM (1999) 1518. In terms of this argument a 9 of the ILC Draft Articles on State Responsibility, which makes provision for the attribution of non-state actors in failed state scenarios, such as Afghanistan is furthermore applicable. It is, however, doubtful that this reasoning depicts the requirements in terms of international law. It must be noted that the legal issues and factual situation in the Tadic case differed from the Nicaragua case. The issue before the Tribunal was that of individual responsibility and the applicable rules of humanitarian international law. It is also worthwhile to take notice of the Tehran Hostage case where the Court formulated the "subsequent approval" formula in terms of which subsequent approval or endorsement of wrongful acts may provide evidence of state responsibility. Par 67; Case Concerning United States Diplomatic and Consular Staff in Tehran (United States of America v Iran) ICJ Report 1980. This test should be applied with caution in the instances of a 51 as it related to the responsibility of Iran in terms of the Vienna Conventions on Diplomatic and Consular Relations. 
not fulfilled in the instance of the Afghanistan case. It seems that in the instance of Afghanistan, Al Qaeda had effective control over the Afghanistan regime. ${ }^{79}$

Although the attacks on the USA were horrific and condemned by most international actors, it is a different question whether the armed response of the USA was valid in terms of international law. A few problems arise regarding this scenario. The fact that a non-state actor instituted the armed attack may be seen as an obstacle to the legitimacy of the actions of the USA. In terms of a theological approach it is possible to construct the attack as an "armed attack" as required by article 51. A second more problematic issue is the question whether the actions of $\mathrm{Al}$ Qaeda can be attributed to the de facto regime of Afghanistan. ${ }^{80}$ This is due to the fact that the Taliban was the target of attack in response to the terrorist actions against the USA. In this instance the "effective control" test is not fulfilled and the acts of $\mathrm{Al}$ Qaeda cannot be attributed to the Taliban, which implies that article 51 cannot serve as a legal ground for the actions of the USA. The armed attack of the USA against Afghanistan was therefore in contravention of article 2(4).

\section{$5 \quad$ The legality of the use of force against Iraq}

\subsection{Authorisation by the Security Council}

In order to determine the legality of the recent attacks on Iraq, it must be established if the UN Security Council resolutions relating to Iraq have authorised the actions of the USA and the UK. It must be borne in mind that the Security Council has not passed a resolution authorising the use of force since Resolution $678^{81}$ was adopted at the start of the Gulf War. This resolution authorised Member States "to use all necessary means to uphold and implement Resolution $660^{82}$ and all subsequent relevant resolutions and

79 Mégret http://www.ejil.org/forum_WTC/ 24.

80 It must be borne in mind that the territorial sovereignty of a de facto regime must also be respected.

81 Security Council Resolution 678 of 1990. The ICJ also referred to the gravity of an attack in the Nicaragua case and emphasized that an armed attack must be on a greater scale and effects than a mere frontier incident. Par 195; Nicaragua case. Resolutions of the Security Council can be found at http://www.un.org/documents/scres.htm 2 Jun. All resolutions relating to Iraq can also be found at http://www.casi.org.uk/info/scriraq.html 2 Jun. It is impossible to explore all resolutions pertaining to Iraq and therefore only the most relevant resolutions will be highlighted.

82 Security Council Resolution 660 of 1990. 
to restore international peace and security in the area". The primary purpose of Resolution 660 was to restore the sovereignty of Kuwait. After the purpose of Resolution 678 was served, a cease-fire was embodied in Resolution $687^{83}$. Iraq accepted the terms contained in the resolution and the provisional cease-fire in Resolution $686^{84}$ was transformed into a permanent cease-fire. ${ }^{85}$

Two arguments in relation to the justification of attacks on Iraq in terms of Security Council Resolutions have been made. The USA and UK have argued that the failure of Iraq to comply with the terms of Resolution 687 has renewed the authorisation to use force in terms of Resolution 678. ${ }^{86}$ The USA for example argued that Iraq had breached the cease-fire by its contravention of obligations in terms of Resolutions 687, $707^{87}, 715^{88}, 1154^{89}, 1194^{90}$ and $1205^{91}$. The coalition forces therefore used force and initiated Operation Desert Fox in 1998 to uphold Resolution 678. Resolution 687 contains a cease-fire agreement between Iraq and the United Nations that has the sole purpose to bring the Gulf War to an end. It furthermore contains requirements that Iraq needs to accept. The cease-fire was conditional on the acceptance of these terms. The cease-fire came into force due to the fact that Iraq accepted the requirements of the cease-fire. $^{92}$ The general prohibition of force applied again in full and a material breach of the requirements of the cease-fire does not give individual members the right to use armed force without the authorisation of the Security Council. ${ }^{93}$ The Security Council is the party to the cease-fire and it must decide whether a material breach has occurred regarding the agreement and which type of response is needed. The argument of the US ignores the way in which the United Nations takes recourse to chapter VII of the Charter where the use of force is required. Limited resources and capacity problems restricted the UN to develop an enforcement mechanism against acts of

83 Security Council Resolution 687 of 1991.

84 Security Council Resolution 686 of 1991.

85 Lobel and Ratner 1999 AJIL 148. Resolution 687 contains detailed requirements, such as the destruction of chemical and biological weapons with a range greater than one hundred and fifty kilometres; the setting up of a demilitarised zone; resolving the border dispute between Iraq and Kuwait and the continuance of economic sanctions against Iraq.

86 Gray 2002 EJIL 12.

87 Security Council Resolution 707 of 1991.

88 Security Council Resolution 715 of 1995.

89 Security Council Resolution 1154 of 1998.

90 Security Council Resolution 1194 of 1998.

91 Security Council Resolution 1205 of 1998.

92 Lobel and Ratner 1999 AJIL 149. 
aggression or breaches of peace. ${ }^{94}$ The Security Council therefore needs to rely on its members to enforce military sanctions. This is done by way of authorisation through resolutions where the Security Council still remains in control. Individual members accordingly act under supervision and in terms of the authorisation of the Security Council. It would be absurd and contrary to the objectives of the Charter if an authorisation implied a permanent mandate for members to unilaterally decide when a cease-fire is breached and when force must be used. It is therefore for the Security Council to decide whether the contravention of a cease-fire agreement should be answered by resuming to the use of force.

Another argument states that Security Council Resolutions implicitly authorised the use of force where Iraq has contravened its obligations. ${ }^{95}$ This argument has also been used to justify Operation Desert Fox when Iraq refused to co-operate with weapons inspectors. The UK and USA referred to Resolutions 1154 and 1205 as the basis for the justification of their actions. These resolutions did not expressly provide for the use of force. The first resolution stated that Iraq must allow unrestricted access to weapons inspectors and indicated that a violation of the resolution would have the severest consequences for Iraq. ${ }^{96}$ Resolution 1205 condemned the decision of Iraq not to co-operate with the weapons inspectors. ${ }^{97}$ It was therefore argued that Resolution 1205 revived the authority to use force contained in Resolution 678. The question is whether Resolution 1154 read with Resolution 1205 implicitly authorises the use of force. The Namibia Advisory Opinion ${ }^{98}$ provides guidance in relation to the interpretation of resolutions of the Security Council and states that:

The language of a resolution should be carefully analysed ... having regard to the terms of the resolution to be interpreted, the discussions leading to it, the Charter provisions invoked and, in general, all circumstances that might assist in determining the legal consequences.

93 Lobel and Ratner 1999 AJIL 144; Murswiek 2003 NJW 1016.

94 In terms of a 43 of the UN Charter, members were supposed to make forces available to the Security Council to ensure that the Security Council could enforce peace measures. This has not occurred. In terms of a 106 the implementation of military sanctions is, however, possible in the absence of the fulfilment of a 43. Randelzhofer The Charter 127.

95 Gray 2002 EJIL 11.

96 Par 3.

97 Par 1.

98 Legal Consequences for States of the Continued Presence of South Africa in Namibia (South West Africa) Notwithstanding Security Council Resolution 278 (1970): Advisory Opinion ICJ Reports 1971. The court suggested an approach similar to that of a 31(1) of the Vienna Convention. 
The wording of Resolutions 1154 and 1205 makes it clear that the Security Council has not authorised the use of armed force. The Security Council did not repeat the phrasing in Resolution 678, which states that "all necessary means" be used. The usage of the phrase "severest consequences" is not an authorisation for Member States, but it rather serves as a warning for Iraq. During discussions in the Security Council following Operation Desert Fox ${ }^{99}$ it was clear that the majority of Member States did not view Resolution 1205 as implicitly reviving the authority to use force in Resolution 678. ${ }^{100}$ To allow members to act in terms of implied authorisation included in Security Council Resolutions would furthermore lead to the abuse of these resolutions. Member States may therefore declare that they are acting in terms of an implicit authorisation in order to promote self-interest. This would create legal uncertainty and would furthermore lead to the abuse of chapter VII. Accepting an implicit authorisation for the use of force would amount to a contravention of one of the main objectives of the UN Charter, which is the promotion of peace.

Resolution 1441 is the latest resolution that contains extensive provisions regarding the weapons inspection regime. ${ }^{101}$ This resolution does not contain an authorisation of the use of force against Iraq even when the latter does not comply with the obligations of the Resolution. ${ }^{102}$ The wording of the resolution is to the effect that although it is recognized that Iraq is in material breach of its obligations, it is still the Security Council that needs to decide what the appropriate answer to this breach will be. ${ }^{103}$ This resolution, just as the others, therefore does not serve as a legal basis for the attack on Iraq. The USA and UK therefore attacked Iraq without authorisation from the Security Council.

99 The USA and UK instituted Operation Desert Fox in 1998 in response to fact that Iraq did not cooperate with UN weapon inspectors.

100 Gray 2002 EJIL 12. This issue was also debated after the UK and USA attacked Iraq radar installations and command centres in February 2001. Russia, China and France viewed these strikes as illegal.

101 Par; Security Council Resolution 1441 of 2002.

102 Par 1 states that Iraq is and has been in breach of previous resolutions, which includes Resolution 687. Par 13 refers to the fact that Iraq has been warned of the serious consequences it faces due to the violation of its obligations.

103 Par 14 states that the Security Council "remain seized of the matter". 


\subsection{The pre-emptive use of force}

The plan to attack Iraq was primarily based on the argument of the USA that Iraq has continued the development of weapons of mass destruction and might use these weapons against opponents or supply these weapons to terrorist networks. ${ }^{104}$ The objective was to pre-empt this danger by removing the regime from power. This strategy is therefore based on the concept of pre-emptive self-defence. ${ }^{105}$ Is this doctrine in line with article 51 of the UN Charter? In terms of the wording of article 51 the element of armed attack must be present to invoke the notion of self-defence. This is supported by the ruling in the Nicaragua case that the right to self-defence exists only in the instance of an armed attack. ${ }^{106}$ The court indicated that an armed attack does not only refer to action by regular forces across an international border, but may also include:

[T]he sending by or on behalf of a State of armed bands, groups, irregulars or mercenaries, which carry out acts of armed force against another State of such gravity as to amount to ... an actual armed attack conducted by regular forces.

The Parties in this case did not rely on the issue of a threat of an imminent armed attack and the court therefore did not rule on this issue. ${ }^{107}$ The question whether anticipatory self-defence will be lawful was therefore never addressed. The point in time from which measures of self-defence against an armed attack may be taken remains unclear.

The Caroline case has been widely cited to answer this issue. This case has commonly been accepted as indicating when the customary law of self-defence can be invoked. In terms of this case anticipatory self-defence is permitted when it can be shown that a "necessity of self-defence, instant, overwhelming, leaving no choice of means, and no moment for deliberation" exists. ${ }^{108}$ This case, however, represented the customary law prior to the existence of the Charter and it is unclear whether article 51 precludes the

104 O'Connel http://www.asil.org/taskforce/oconnell.pdf 12 Aug.

105 President Bush referred to pre-emption at a Graduation Speech at West Point in May 2002. To be found at: http://www.whitehouse.gov/news/releases/ 2002/06/20020601-3.html 2 Jun. This concept has also been included in the National Security Strategy of the USA of September 2002. To be found at: www.whitehouse.gov/nsc/nss.pdf 3 Jun.

106 Par 194-195, 211; Nicaragua case.

107 Par 194. 
customary law in this regard and therefore precludes a right to anticipatory selfdefence. This uncertainty stems from the inclusion of the term "inherent" in article 51. The prevailing view (and in the opinion of the author, correct view) is that, taking account of the objective of the Charter, article 51 excludes any self-defence other than that being launched in response to an armed attack. ${ }^{109}$ It must be kept in mind that the customary right of self-defence is unclear and that its existence could even extend to the unilateral use of force by countries. The term "inherent" rather implies that the right of self-defence is also available to non-UN members. Disagreement exists amongst international lawyers regarding the point in time from which self-defence may be invoked. ${ }^{110}$ The more correct view is that anticipatory self-defence is not recognized by article 51 . The recognition of this doctrine may result in abuse as the requirements of this principle are vague and may be left to the discretion of States, which will easily justify their actions as anticipatory. Although this issue is of interest in relation to the law of force, it is not of much relevance regarding the Bush doctrine of pre-emptive force. This doctrine entails a right of self-defence for possible or potential threats that may occur in the future. Even the acceptance of a right to anticipatory self-defence based on the requirements of the Caroline case will not justify a right to pre-emptive defence. Pre-emptive defence relates to a hypothetical potential threat, which has not occurred or has not begun to occur. This scenario clearly exceeds the criteria of the Caroline case. The doctrine of pre-emptive strike is not recognized in terms of international public law and contravenes article 2(4). ${ }^{111}$

The pre-emptive strike doctrine is nothing more than offensive measures in disguise and does not adhere to the requirements of self-defence. Anarchy will be the result where other states follow the lead (and the doctrine) of the USA. States may decide that they do not trust other states which they regard as enemies and therefore invoke pre-emptive defence. This will undermine the international regime and will lead to a

108 Harris International Law 848.

109 Randelzhofer The Charter 792. Brownlie also cautions against using the Caroline incident in isolation due to the fact that it relates to a period before the modern legal regime. Brownlie Rule of Law 203.

110 See for various opinions: Harris International Law 849-851. O'Connel is of the opinion that anticipatory self-defence is allowed in terms of international law where it is in response to incipient attacks and ongoing campaigns. O'Connel http://www.asil.org/taskforce/oconnell.pdf 8 and 11. She is of the opinion that: "a state need not wait to suffer the actual blow before defending itself, so long as it is certain the blow is coming". Concurring, Murswiek 2003 NJW 1016-1018.

111 This statement is supported by O'Connel http://www.asil.org/taskforce/oconnell.pdf and Murswiek 2003 NJW 1018. 
situation where force is an accepted mechanism of regulating international affairs. This was the view that was generally accepted by international lawyers in the nineteenth century when the distinction between bellum justum and bellum injustum was irrelevant. ${ }^{112}$ The opinion exists that this acceptance:

... brought the theory of law into accord with what had always been and still remained the facts of international practice." 113

This statement came back to hunt international lawyers in the twenty first century due to the illegal invasion of Iraq by the USA. It seems that the theory of law has been brought into accord with the practice that the superpower will act in disregard of the international regime. It is, however, clear that it does not want other states to enjoy the same rights. Historically, the USA has argued against a right of pre-emptive selfdefence and played a leading role in the adoption of the UN Charter. ${ }^{114}$ The reason for the position of the USA was that although the Charter rules can restrict the USA, it is worthwhile due to the fact that it restricts other states as well. It is clearly not in the interest of the USA if states invoke pre-emptive self-defence in order to attack other states.

The USA has decreed a new doctrine through its acts where it may not only choose to impose pre-emptive force:

... when and where it chooses, but the nation will also punish those who engage in terror and aggression and will work to impose a universal moral clarity between good and evil." 115

This pre-emptive defence will ultimately be employed to enforce good. These criteria are clearly vague. What is good and who has the competence to decide on this matter? The USA will ultimately decide what universal good entails. It has been argued that a situation may arise where a sui generis set of rules pertain to the USA and another set of rules apply to other states. ${ }^{116}$ The acceptance of this line of argument once again reflects the view of a "supposed realist". The mere fact that the USA is acting as if a

112 Randelzhofer The Charter 114.

113 Harris International Law 817.

114 O'Connel http://www.asil.org/taskforce/oconnell.pdf 16.

115 Graduation speech of George W Bush at West Point in May 2002.

116 Byers 2002 EJIL 38. 
sui generis set of rules applies, does not mean that this violation of international law should be condoned by giving this non-adherence legal status. The role of domination that the USA plays is not a basis for the creation of new rules pertaining to the formation of customary law. Realistic and unacceptable practice should be distinguished from what the law prescribes. The notion of a set of sui generis rules violates the principle of sovereign equality. Has this principle also been rewritten by the actions of the USA? ${ }^{117}$ This is clearly not the case. ${ }^{118}$ No doubt can therefore exist that the attack on Iraq was in contravention of article 2(4) of the UN Charter.

\section{Conclusion}

This article explored three instances where primarily the USA and UK used force against other states during the past ten years. The purpose of this investigation is to examine the legality of the coercive measures in order to ascertain the effects that these actions had in relation to article 2(4) of the Charter. The proposed justifications for the attacks differ. In the instance of the use of armed force in Kosovo, the concept of humanitarian intervention was used as a ground for justification. ${ }^{119}$ The attack on Afghanistan was in response to the terrorist attacks that were launched against the USA during 2001. The use of force in Iraq was mainly based on the doctrine of pre-emptive force. The reaction of the international community also differed in relation to these actions. The international community mostly granted support to the armed interventions that took place in Kosovo and Afghanistan, while the attack on Iraq was met by international resistance. These actions were more readily accepted by states in the instance of Kosovo due to the multilateral nature of the armed intervention as well as the moral compelling reasons to

117 A 2(1) of the Charter.

118 The Charter cannot be easily amended. In terms of a 103 the Charter for instance overrides all inconsistent treaties regardless of the date of their entry into force. A 108 of the Charter states that an amendment will come into force when it has been adopted by two thirds of the members of the General Assembly and ratified in terms of their constitutional processes by two thirds of the members of the UN, which must include all the permanent members of the Security Council.

119 It must be noted that he USA did not rely on the notion of humanitarian intervention to justify its actions, but it rather stressed political and moral considerations in this regard. The concept of humanitarian intervention is something, which authors of international public law have focused on. In the pending case before the ICJ, the Legality of the Use of Force, the defendant states did not rely on the concept of humanitarian intervention. Only Belgium referred to past practice regarding humanitarian intervention. 
intervene. The gravity of the terrorist attacks in 2001 also contributed to the support that the USA received for its attack against Afghanistan. The attack on Iraq was against the wishes of the majority of the states of the world. The actions of the USA indicate that it may not perceive the jus ad bellum to be binding and accordingly finds it unnecessary to engage in lengthy arguments to justify its actions. This is the result of the developments that took place especially during the past decade. The development of the notion of humanitarian intervention is a reaction to the atrocities committed in contravention of human rights and for which the Charter does not provide an adequate response. The doctrine of pre-emptive force is also an apology of power for the actions of the USA. The attacks against Afghanistan in response to the September 11 attacks are also debatable. The commonality that exists between the three cases, is the illegality attached to the actions of primarily the USA and the UK.

The failure of the Security Council to preserve peace implies that the United Nations has failed in the realization of one of its main objectives. The question is whether a solution could be found to ensure that the Security Council would be able to preserve peace? The way in which the Security Council needs to rely on the armed forces of members in order to deter aggression is the main source of the problem. This model may have opened the door for the abusive use of coercive measures by members of the Security Council. This was the case in Iraq in 2003 where certain members have subsequently illegally attacked Iraq on the basis of Resolution 678. This may have been different if the Security Council had troops at its disposal as envisaged in article 43 of the UN Charter. The Security Council would have direct command over the armed forces. Members that acted independently would then not be able to hide behind an implicit authorization in a resolution. It would therefore be logical to propose that article 43 must be adhered to. Article 43 has never been utilized and it is not envisaged that it would ever become operational.

This would, however, not address the way in which article 27(3) determines the voting procedure of the Security Council, which makes provision for the right of a veto for a permanent member. This seems to be the main reason for members of the Security Council to act in the absence of authorization. The availability of armed forces to the Security Council would not solve this problem. It is most probable that the deployment of such a force would have been vetoed in the Kosovo case. This would also not have 
avoided the unilateral attack on Iraq, due to the lack of support for this action in the Security Council. The problem must be addressed at its source. Members can agree to an amendment of article 27 of the $U N$ Charter, which will ensure a more efficient mechanism that could respond to threats of international peace. It is, however, the opinion of the author that this would also not be an optimal solution. ${ }^{120}$ Article 27 contains cumbersome provisions for a very good reason and that is to ensure that the object of ensuring international peace is not disturbed. This provision creates a system, which ensures that members of the Security Council does not abuse this mechanism to employ armed force against other States. It is clear from the objectives of the UN Charter and article 2(4) that the deployment of armed forces authorized by the Security Council cannot be easily undertaken. An amendment of article 27 would allow members of the Security Council to use the council to endorse its unilateral armed operations. This would frustrate the realization of international peace.

This statement suggests that it does not seem that the Security Council will be successful in curtailing the illegal acts of major powers, such as the USA. This does not imply that article 2(4) is irrelevant. States should continue to support the jus ad bellum and should not accept actions that contravene this provision. It is not perfect, but it is the only measure that can preclude anarchy relating to the use of force in the international arena.

120 It is therefore not worthwhile to investigate and propose an amendment. The strict requirements for amendment of the Charter, makes it doubtful whether such a proposal would even succeed. 


\section{Bibliography}

Bennoune 2002 EJIL 243-262

Bennoune K "Sovereignty vs. Suffering? Re-examining Sovereignty and Human

Rights through the lens of Iraq" 2002 (13) EJIL 243-262

Brownlie Rule of Law

Brownlie I The Rule of Law in International Affairs: International Law at the fiftieth Anniversary of the United Nations (M Nijhoff Dordrecht 1998)

Byers 2002 EJIL 26-38

Byers M "The Shifting Foundations of International Law: A Decade of Forceful Measures Against Iraq" 2002 (13) EJIL 26-38

Cassese 1999 EJIL 23-27

Cassese A "Ex Iniuria Oritur: Are We Moving towards International Legitimation of Forcible Humanitarian Countermeasures in the World Community?" 1999 (10) EJIL 23-27

Cohn 2002 IJSL 79-106

Cohn M "Nato Bombing of Kosovo: Humanitarian Intervention or Crime Against Humanity?" 2002 (15) IJSL 79-106

Danilenko Law-Making

Danilenko GM Law-Making in the International Community (M Nijhoff Dordrecht 1993)

De Wet Powers of the UN

De Wet E The Chapter VII Powers of the United Nations Security Council (Hart Oregon 2004)

Doehring Völkerrecht

Doehring K Völkerrecht (CF Muller Heidelberg 1999) 
Dugard International Law

Dugard J International Law: A South African Perspective (Juta Cape Town 1994)

Franck 2001 AJIL 839-838

Franck TM "Terrorism and the Right of Self-defence" 2001 (95) AJIL 839-838

Harris International Law

Harris DJ Cases and Materials on International Law $4^{\text {th }}$ ed (Sweet and Maxwell London 1994)

Gazzini 2002 EJIL 391-435

Gazzini T "Nato Coercive Military Activities in the Yugoslav Crisis (1992-1999)" 2002 (12) EJIL 391-435

Gray 2002 EJIL 1-19

Gray C "From Unity to Polarization: International Law and the Use of Force Against Iraq" 2002 (13) EJIL 1-19

Hilpold EJIL 437-467

Hilpold P "Humanitarian Intervention: Is there a Need for a Legal Reappraisal?" 2001 (12) EJIL 437-467

Krisch 2002 EJIL 323-335

Krisch N "Review Essay Legality, Morality and the Dilemma of Humanitarian Intervention after Kosovo" 2002 (13) EJIL 323-335

Kritisiotis 2000 ICLQ 330-359

Kritisiotis N "The Kosovo Crisis and NATO's Application of Armed Force Against the Federal Republic of Yugoslavia" 2000 (49) ICLQ 330-359

Lobel and Ratner 1999 AJIL 144-149

Lobel J and Ratner M "Bypassing the Security Council: Ambiguous Authorizations to Use Force, Cease-Fires and the Iraq Inspection Regime" 1999 (93) AJIL 144-149 
Murphy 2002 AJIL 237-263

Murphy SD "Contemporary Practice of the United States Relating to International Law" 2002 (96) AJIL 237-263

Murswiek 2003 NJW 1016-1018

Murswiek D "Die amerikansiche Präventskriegsstrategie und das Völkerrecht" 2003 (14) NJW 1016-1018

Randelzhofer The Charter

Randelzhofer A "The Charter" in Simma B et al (eds) The Charter of the United Nations A Commentary I $2^{\text {nd }}$ ed (Oxford University Press Oxford 2002)

Reisman 2001 AJIL 833-835

Reisman WM "In Defense of World Public Order" 2001 (95) AJIL 833-835

Roberts 2001 AJIL 757-791

Roberts AE "Traditional and Modern Approaches to Customary International Law: A Reconciliation" 2001 (95) AJIL 757-791

Schachter International Law

Schachter International Law in Theory and Practice (M Nijhoff Dordrecht 1991)

Stahn 2002 ZaoRV 211-221

Stahn G "International Law at Crossroads: The Impact of September 11" 2002 (62) ZaoRV 211-221

Strydom 1989 JJS 36-44

Strydom HA "Enkele Aspekte van die Soewereiniteitsvraag in die Volkereg" 1989 (14) JJS 36-44

Strydom 1988/1989 SAYIL 44-58

Strydom HA "Ius Cogens: Peremptory Norm or Totalitarian Instrument?" 1988/1989 (14) SAYIL 44-58 
Sulyok 2000 Acta Juridica Hungarica 79-109

Sulyok G "Humanitarian Intervention: A Historical and Theoretical Overview" 2000 Acta Juridica Hungarica 79-109

Thürer 2000 Archiv des Völkerrechts 1-22

Thürer D "Der Kosovo Konflikt im Lichte des Völkerrechts: Von Drei- Echten und Scheinbaren- Dilemmata" 2000 (1) Archiv des Völkerrechts 1-22

Williams 2002 Vereinte Nationen Zeitschrift für die VN 10-16

Williams I "Nur das Letzte Mittel Der Bericht der Axworthy-Kommission zur Humanitären Intervention" 2002 (1) Vereinte Nationen Zeitschrift für die Vereinte Nationen und ihre Sonderorganizationen 10-16

\section{Register of Cases}

Barcelona Traction, Light and Power Company, Ltd Second Phase ICJ Reports 1970 Legal Consequences for States of the Continued Presence of South Africa in Namibia (South West Africa) Notwithstanding Security Council Resolution 278 (Advisory Opinion) ICJ Reports 1971

Legal Consequences of the Construction of a Wall in the Occupied Palestinian Territory (Advisory Opinion) ICJ Reports 2004

Nicaragua v United States of America (Merits Judgement) ICJ Reports 1986

Prosecutor v Tadic 15 July 1999 ILM Vol 38 (1999) 1518

United States of America v Iran ICJ Report 1980

\section{Treaties and other international sources}

Charter of the United Nations

Convention on the Prevention and Punishment of the Crime of Genocide 1948

Convention against Torture and Other Cruel Inhuman or Degrading Treatment or Punishment 1984

Convention on the Rights of the Child 1989 
Declaration on the Elimination of Discrimination against Women 1979

Declaration on Principles of International Law

Definition of Aggression GA Resolution 3314 (XXIX) UN Doc A/9631 (1974)

GA Resolution 2625 (XXV) 24 October 1975

International Covenant on Civil and Political Rights 1966

International Covenant on Economic, Social and Cultural Rights 1966

Security Council Resolution 660 of 1990

Security Council Resolution 678 of 1990

Security Council Resolution 686 of 1991

Security Council Resolution 687 of 1991

Security Council Resolution 707 of 1991

Security Council Resolution 715 of 1995

Security Council Resolution 1154 of 1998

Security Council Resolution 1194 of 1998

Security Council Resolution 1205 of 1998

Security Council Resolution 1244 of 1999

Security Council Resolution 1368 of 2001

Security Council Resolution 1373 of 2001

Security Council Resolution 1441 of 2002

Vienna Convention on the Law of Treaties 1969

\section{Register of Internet resources}

Charney http://www.asil.org/ajil/kosovo.htm 1 Aug

Charney JI "NATO's Campaign in Yugoslavia in: Editorial Comments: Nato's Kosovo Intervention" [Found on Internet] http://www.asil.org/ajil/kosovo.htm [Date of use 1 Aug 2003] 
Declaration of G77 http://www.nam.gov.za/documentation/southdecl.htm 9 Jun

Declaration of the Group of 77 "South Summit: Cuba, Havana 10-14 April 2000"

[Found on Internet] http://www.nam.gov.za/documentation/southdecl.htm [Date of use 9 Jun 2003]

Falk http://www.asil.org/ajil/kosovo.htm 7 Jun

Falk RA "Kosovo, World Order and the Future of International Law in: Editorial

Comments: Nato's Kosovo Intervention" [Found on Internet]

http://www.asil.org/ajil/kosovo.htm [Date of use 7 Jun 2003]

Franck http://www.asil.org/ajil/kosovo.htm 12 Jun

Franck TM "Lessons of Kosovo in: Editorial Comments: Nato's Kosovo

Intervention" [Found on Internet] http://www.asil.org/ajil/kosovo.htm [Date of use

12 Jun 2003]

Henkin http:// www.asil.org/ajil/kosovo.htm 1 Jun

Henkin L "Kosovo and the Law of 'Humanitarian Intervention"' [Found on Internet] http:// www.asil.org/ajil/kosovo.htm [Date of use 1 Jun 2003]

Kirgis http://www.asil.org/insights/insigh30.htm 8 Aug

Kirgis FL "The Kosovo Situation and NATO Military Action" [Found on Internet] http://www.asil.org/insights/insigh30.htm [Date of use 8 Aug 2003]

Köchler http://www.i-p-o.org/koechler-intervention.pdf 20 Jun

Köchler H "Use of Force in the New International Order: On the Problematic Nature of the Concept of Humanitarian Intervention" [Found on Internet] http://www.i-po.org/koechler-intervention.pdf [Date of use 20 Jun 2003]

Lee http://www.bu.edu/wcp/Papers/Poli/PoliLee.htm 14 Jun

Lee SA "Puzzle of Sovereignty" [Found on Internet]

http://www.bu.edu/wcp/Papers/Poli/PoliLee.htm [Date of use 14 Jun 2002]

Mégret http://www.ejil.org/forum_WTC/ 3 Aug

Mégret F "War? Legal Semantics and the Move to Violence"

http://www.ejil.org/forum_WTC/ [Date of use 3 Aug 2003] 
Mertus http://www.asil.org/insights/insigh31.htm 7 Jun

Mertus J "Human Rights Should Know No Boundaries" [Found on Internet] http://www.asil.org/insights/insigh31.htm [Date of use 7 Jun 2003]

Moore http://www.fed-soc.org/Publication/Transcripts/useofforce.htm10 Jun Moore JN et al "International Law and the Use of Force" [Found on Internet] http://www.fed-soc.org/Publication/Transcripts/useofforce.htm [Date of use 10 Jun 2003]

O'Connel http://www.asil.org/taskforce/oconnell.pdf 12 Aug O'Connel ME "The Myth of Preemptive Self-defence" [Found on Internet] http://www.asil.org/taskforce/oconnell.pdf [Date of use 12 Aug 2003]

Press Release http://www.maknews.com/html/articles/un_res_1371.htm 3 Jul Press Release "SC/7153" http://www.maknews.com/html/articles/un_res_1371.htm [Date of use 3 Jul 2003]

Reisman http://www.asil.org/ajil/kosovo.htm 9 Jun

Reisman WM "Kosovo's Antinomies in Editorial Comments: Nato's Kosovo Intervention" [Found on Internet] http://www.asil.org/ajil/kosovo.htm [Date of use 9 Jun 2003]

Various authors http://www.whitehouse.gov/news/releases/2002/06/20020601-3.html [Date of use 2 Jun 2003] http://www.ejil.org/forum_WTC [Date of use 2 Aug 2003] http://www.asil.org/terrorind.htm [Date of use 2 Aug 2003] http://www.un.org/documents/scres.htm [Date of use 2 Jun 2003] http://www.casi.org.uk/info/scriraq.html [Date of use 2 Jun 2003] http://www.whitehouse.gov/nsc/nss.pdf [Date of use 3 Jun 2003] 